University of New Hampshire

University of New Hampshire Scholars' Repository

$12-2007$

\title{
Ski areas, weather and climate: Time series models for New England case studies
}

\author{
Lawrence C. Hamilton \\ University of New Hampshire, lawrence.hamilton@unh.edu \\ Cliff Brown \\ University of New Hampshire - Main Campus \\ Barry D. Keim \\ Louisiana State University
}

Follow this and additional works at: https://scholars.unh.edu/soc_facpub

Part of the Sociology Commons

\section{Comments}

This is the pre-/peer reviewed version of the following article: Hamilton, L.C., Brown, C., Keim, B.D. Ski areas, weather and climate: Time series models for New England case studies. (2007) International Journal of Climatology, 27 (15), pp. 2113-2124, which has been published in final form at https://dx.doi.org/10.1002/joc.1502. This article may be used for non-commercial purposes in accordance with Wiley Terms and Conditions for Self-Archiving.

\section{Recommended Citation}

Hamilton, L.C., Brown, C., Keim, B.D. Ski areas, weather and climate: Time series models for New England case studies. (2007) International Journal of Climatology, 27 (15), pp. 2113-2124.

This Article is brought to you for free and open access by the Sociology at University of New Hampshire Scholars' Repository. It has been accepted for inclusion in Sociology Scholarship by an authorized administrator of University of New Hampshire Scholars' Repository. For more information, please contact Scholarly.Communication@unh.edu. 
AUTHORS' DRAFT. Final version published at:

Hamilton, L.C., B.C. Brown \& B.D. Keim. 2007. "Ski areas, weather and climate: Time series models for New England case studies." International Journal of Climatology 27:2113-2124. doi: 10.1002/joc. 1502

\title{
SKI AREAS, WEATHER AND CLIMATE: TIME SERIES MODELS FOR NEW ENGLAND CASE STUDIES
}

Lawrence C. Hamilton

Sociology Department

University of New Hampshire

Cliff Brown

Sociology Department

University of New Hampshire

Barry D. Keim

Department of Geography and Anthropology

Louisiana State University

\begin{abstract}
Wintertime warming trends experienced in recent decades, and predicted to increase in the future, present serious challenges for ski areas and whole regions that depend on winter tourism. Most research on this topic examines past or future climate-change impacts at yearly to decadal resolution, to obtain a perspective on climate-change impacts. We focus instead on local-scale impacts of climate variability, using detailed daily data from two individual ski areas. Our analysis fits ARMAX (autoregressive moving average with exogenous variables) time series models that predict day-to-day variations in skier attendance from a combination of mountain and urban weather, snow cover and cyclical factors. They explain half to two-thirds of the variation in these highly erratic series, with no residual autocorrelation. Substantively, model results confirm the "backyard hypothesis" that urban snow conditions significantly affect skier activity; quantify these effects alongside those of mountain snow and weather; show that previous-day conditions provide a practical time window; find no monthly effects net of weather; and underline the importance of a handful of high-attendance days in making or breaking the season. Viewed in the larger context of climate change, our findings suggest caution regarding the efficacy of artificial snowmaking as an adaptive strategy, and of smoothed yearly summaries to characterize the timing-sensitive impacts of weather (and hence, high-variance climate change) on skier activity. These results elaborate conclusions from our previous annual-level analysis. More broadly, they illustrate the potential for using ARMAX models to conduct integrated, dynamic analysis across environmental and social domains.
\end{abstract}




\section{INTRODUCTION}

Climate change presents challenges to a wide range of tourism-based economies, and to places depending on winter tourism in particular (ACACIA 2000; Gössling and Hall 2005; OECD 2007; World Tourism Organization 2003). For many such places, climate change appears not merely as a future hypothesis, but as a process already underway. During the late 20th century, winter-recreation areas often saw departures from their historical climates. In some mountain and northern regions snow cover was lighter, arrived later in fall, or left earlier in spring; it became more restricted to higher elevations or latitudes; it more often confronted warm spells, snow drought or rain (e.g., Huntington et al. 2004; Laternser and Schneebeli 2003; Mote et al. 2005; Nolan and Day 2006; Scherrer et al. 2004). Global climate models suggest that greater changes lie ahead, driven by greenhouse gas buildup (e.g., IPCC 2001). Regional modeling applications explore impacts of climate change for particular winter-recreation areas (e.g. Elsasser and Bürki 2002; Scott forthcoming). The growing literature on this topic includes both retrospective studies analyzing impacts of recent observed change, and prospective studies exploring implications of future warming. Studies of both types often take a regional view, because the geography of climate change and winter tourism vary on fine scales. Specific wintertourism regions of interest have included Eastern North America (Scott et al. 2006a), the Great Lakes (McBoyle and Wall 1992), New England (Scott 2006), New Hampshire (Palm 2001; Hamilton et al. 2003a), Vermont (Badke 1991), Ontario (Scott et al. 2003), Quebec (Scott et al. 2006b), the European Alps (OECD 2007), Switzerland (Beniston et al. 2003a, 2003b; Elsasser and Messerli 2001; Koenig and Abegg 1997), Austria (Breiling and Charamaza 1999; Hantel 2000), Australia (Galloway 1988; Koenig 1999) and Japan (Fukushima et al. 2002).

Ski areas, emblematic of winter tourism, provide the economic engine for many rural regions. Their importance extends beyond employment and revenues of the ski area itself. Real estate booms in second homes and condominiums, and in-migration by retirees and others, raise housing prices and transform communities in fundamental ways. Tax revenues, businesses, and the needs for infrastructure and social services change as well. The impacts can be regional, not confined to the ski towns (e.g., Palm 2001). If climate shifts directly affect ski areas, their indirect impacts ripple as well. Ski areas in marginal snow areas become stressed first, and many have in fact gone out of business (NELSAP 2006; Hamilton et al. 2003a). Others survive through escalating investments in snowmaking, which raise the cost of staying in business - and of skiing. Future prosperity for downhill ski areas will depend on more snowmaking, although other snow sports such as cross-country skiing and snowmobiling might not have this option (Scott 2006; Scott et al. 2006a). In recent years, many ski areas have diversified into real estate and year-round recreation, to supplement their snow-season income. If snow-season income declines, other seasons could expand to make up business, but the goals of year-round revenue and employment, and a driver for real estate values, both are challenged. Scott and McBoyle (2006) analyze such diversification strategies and constraints as part of their comprehensive review of climate-change adaptation in the ski industry.

The sharp dependence of ski areas on weather, and the strong patterns of observed and predicted climate change, make this topic particularly appropriate for interdisciplinary analyses of 
society-environment interactions. Most work to date has studied these interactions from the supply side of ski operations. Our analysis focuses instead on the impact of weather on demand.

Local, daily resolution allows a detailed examination of the time and spatial structure of weather effects on skiing. For example, how is skier activity today affected by snow falling today? Or by snow falling yesterday, or the day before that? How consequential is snow in the nearest major city, compared with snow on the ski slopes themselves? Ski areas experience great variations in business from one day to the next, as weekend and holiday cycles interact with unpredictable weather at different locations. Daily resolution could also become more important if, as some models predict and recent observations suggest, climate change involves shifts not just in means but in variances, affecting the probabilities of extreme events such as winter thaws, droughts or rain. Like annual data, daily data allow us to use time as an integrating dimension across social and natural-science domains. Daily data, however, contain far more observations, hence more information or degrees of freedom - new power for hypotheses tests and effect estimation within dynamic multivariate models. The forecasting capabilities of mulivariate daily models could prove to have practical applications as well.

We present two case studies below, exploring the feasibility of this general approach. Time series models are constructed for daily attendance at two New Hampshire ski areas. The highly erratic-appearing fluctuations in daily ski-area attendance, through multiple seasons, prove to be reasonably well predicted from weekly cycles overlaid by irregular snow-cover and weather effects. Because snow and weather follow deeper trends in climate, such work also has implications for understanding the potential future consequences of climate change

\section{CASE STUDIES, DATA AND METHODS}

The New Hampshire ski areas that provide our case studies both date to the 1930s, making them among the nation's oldest alpine resorts. Our northern site, Cannon Mountain, is located above the state's mid-latitude line $\left(44^{\circ} \mathrm{N}\right)$ in the northwestern White Mountains (see map, Figure 1). Our southern site, Gunstock Mountain Resort, is situated below mid-latitude near Lake Winnipesaukee. Both resorts developed during the Great Depression of the 1930s, when large government programs such as the Civilian Conservation Corps and the Works Progress Administration employed thousands in support of new forest, conservation and development initiatives. In New Hampshire, these efforts included the construction of ski trails and resort infrastructure that provided a template for the industry's subsequent growth (Gunstock Mountain Resort 2006; New England Ski Museum 2006). Although they are comparable in size and origins, our sites differ in their topography, elevation, average annual snowfall and proximity to metropolitan markets. 


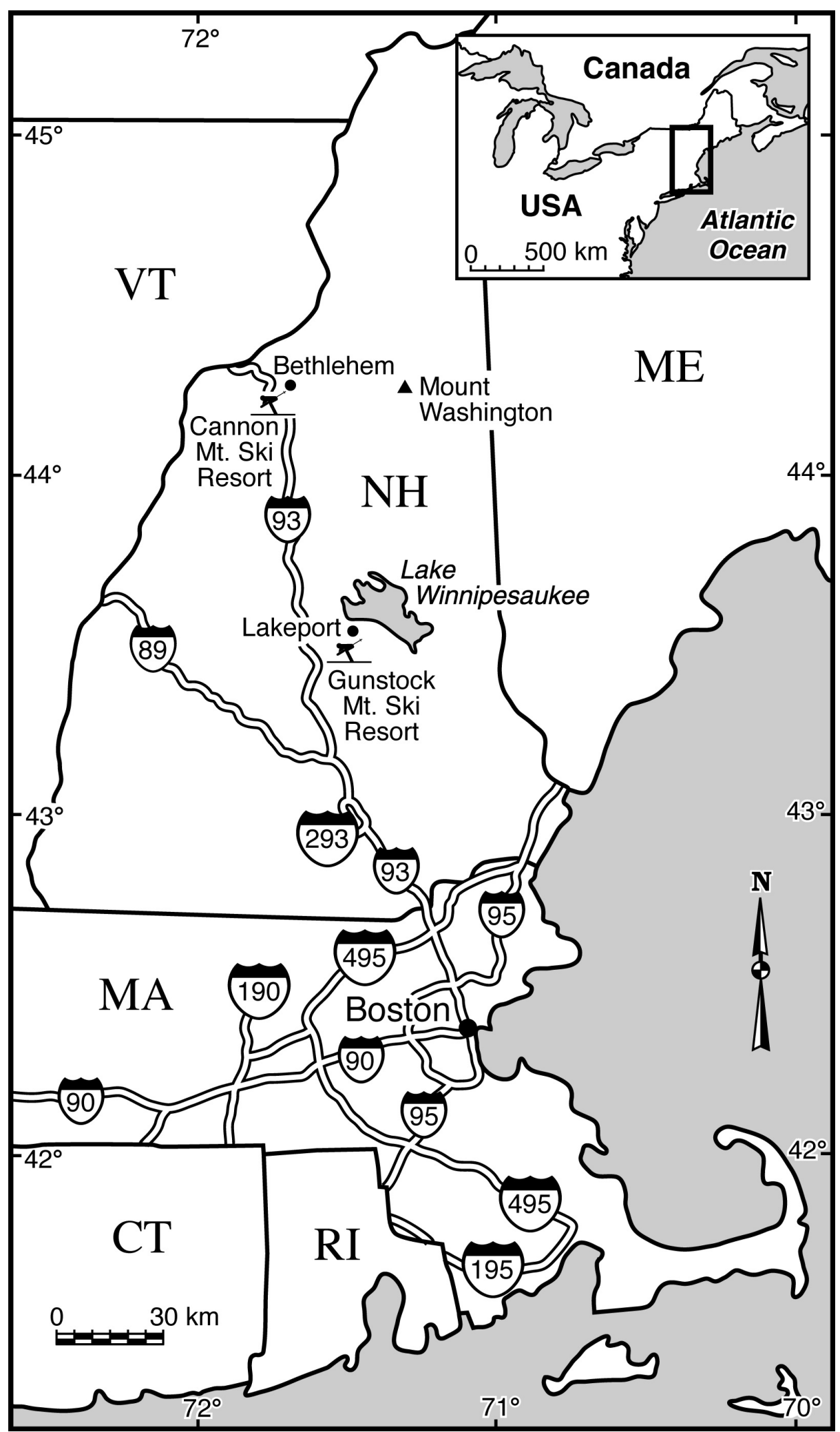

Figure 1: Map showing the locations of case study ski areas in relation to nearby weather stations, the city of Boston, interstate highways and (inset) the northeastern US and Canada. 
Situated in Grafton County's Franconia Notch State Park, Cannon was established in 1933 with the help of the Civilian Conservation Corps. The area served as a prototype for the development of alpine skiing in the northeastern United States. Given its proximity to Interstate 93, the resort is quite accessible, although it is more distant from Boston (about 140 miles or 225 kilometers) and other cities than ski areas located in the lower half of the state. Cannon has 55 trails and nine lifts, a base elevation of 2000 feet (610 meters), and a vertical drop of 2146 feet (654 meters). The resort reports an average of 156 inches (396 centimeters) of snowfall each year. Operated by the New Hampshire Division of Parks and Recreation, the site is also home to the New England Ski Museum (Cannon Mountain 2006; New England Ski Guide 2006; New England Ski Museum 2006; Ski NH 2006a).

Gunstock Mountain Resort, our southern site, is located in the town of Guilford and dates to 1935. It was created with help from the Works Progress Administration and is owned by Belknap County. Gunstock is about 100 miles (161 kilometers) from Boston. It offers 51 trails, seven lifts, a base elevation of 900 feet (274 meters), and a vertical drop of 1400 feet (427 meters). Gunstock reports receiving an average of 100 inches (254 centimeters) of snowfall annually. In keeping with industry-wide trends, both areas have extensive snowmaking capability and offer year-round activities including camping, summer sports, and day camps for children (Gunstock Mountain Resort 2006; New England Ski Guide 2006; Ski NH 2006a).

With the assistance of resort personnel, we were able to obtain records of daily attendance (roughly, counts of skier and snowboarder visits) through seven winter seasons at Cannon (1999-2000 through 2005-06, more than 800 ski-operation days) and nine winters at Gunstock (1997-98 through 2005-06, over 1000 ski-operation days). At Gunstock, the attendance includes nighttime skiing. Our principal findings proved insensitive to minor variations in the definition of "daily attendance."

Weather and snow-condition indicators include daily snowfall, snowdepth and temperature for Boston, Massachusetts, and Lakeport and Bethlehem, New Hampshire. These sites were selected based on geography, and for data completeness and quality. The underlying dataset comes from Climatological Data-New England, published monthly by the National Climatic Data Center, and was provided in digital form by the Southern Regional Climate Center at Louisiana State University. The nuances involved in the collection of snowfall and snowdepth data are fully recognized (Doesken and Judson 1997). We view the Lakeport and Bethlehem weather-station records as imperfect but demonstrably useful proxies for snowfall, snowdepth and temperature conditions at the Gunstock and Cannon ski areas, respectively. Similarly, Boston provides a very rough indicator of conditions in the urban and suburban regions of southern New Hampshire and Massachusetts, where much of the skier/snowboarder population lives. Despite their limitations, these proxies contribute essential predictive power to the models, exhibiting significant and interpretable effects. Better weather/snow measures could lead to stronger effect estimates and more accurate predictions, enhancing the models' practical value. 
Julian dates allowed us to merge daily ski-area and weather/snow datasets - a simple example of using time as the integrating dimension across social and natural-science domains. From the dates we created indicators for winter season, month, day of week, and day of season (arbitrarily starting at $0=$ November 1 each year). A variety of interaction terms (such as weekend $\times$ snowfall) and transformations (such as log attendance and snowdepth) were tried out as well, but these complicated the models without significant improvements in fit, and were subsequently set aside.

Searching for predictability behind day-to-day fluctuations in ski-area attendance, we estimated ARMAX models (autoregressive moving-average models with exogenous variables). The exogenous variables in this case are cyclical factors and present or lagged values of daily weather/snow indicators. The disturbances, standing for "everything else" that affects daily skiarea attendance, were modeled explicitly through autoregressive (AR) and/or moving-average (MA) terms, plus uncorrelated white-noise errors. AR terms reflect the influence on the disturbance of past disturbances (or equivalently, of past values of the dependent variable). MA terms reflect the influence of past random errors. Parameter estimation involves an iterative maximum-likelihood procedure using the Kalman filter (Harvey 1989; Hamilton 1994). Robust standard errors and hypothesis tests for individual coefficients, not requiring the usual (but unrealistic) assumption of homoskedasticity, were obtained via "sandwich" variance estimates (Huber 1967; White 1980, 1982; Royall 1986). Robust standard errors tend to be larger than the usual standard errors, so in this sense our hypothesis tests are more conservative.

Substantial exploratory work informed the modeling process. We show results below from two sets of models, termed "full" (about 24 exogenous variables) and "reduced" (11 exogenous variables). Alternative specifications involving other predictors, lag structures, interaction effects, differencing and transformations were tested along the way. The reduced-model results reported below stood out as more stable, parsimonious, statistically supported and interpretable than the alternatives, and their common specification replicated successfully across the two datasets here. As with any exploratory analysis, our findings invite further replication using independent datasets — which should be straightforward.

Some key findings have been visualized in displays influenced by Edward Tufte's call (1990, 1997, 2001) for designing clear, information-rich graphics that allow viewers to draw their own comparisons and examine details of relationships between variables. All graphical, database and modeling work was conducted with Stata (Stata 2005a, 2005b; Mitchell 2004; for an overview see Hamilton 2006).

\section{RESULTS}

Looking at daily skier-attendance data, one notices first its within-season heterogeneity. Figure 2 graphs the cumulative percentage of total attendance (number of skier/snowboarder visits) over the ski season against the cumulative percentage of days. A consistent pattern appears: at both 
Gunstock and Cannon, and with only minor variation across seven ski seasons, the least-busy $50 \%$ of the days accounted for less than $20 \%$ of the season's total attendance. In contrast, the busiest $10 \%$ of the days accounted for about $30 \%$ of the attendance each season. The percentage of total revenues earned on the best $10 \%$ of days substantially exceeds $30 \%$, due to the higher lift-ticket prices during weekend and holiday periods. Figure 2 illustrates the disproportionate importance of just a handful of good days each season. These critical days usually include the post-Christmas and February school vacations, but weather can depress those periods or elevate others.
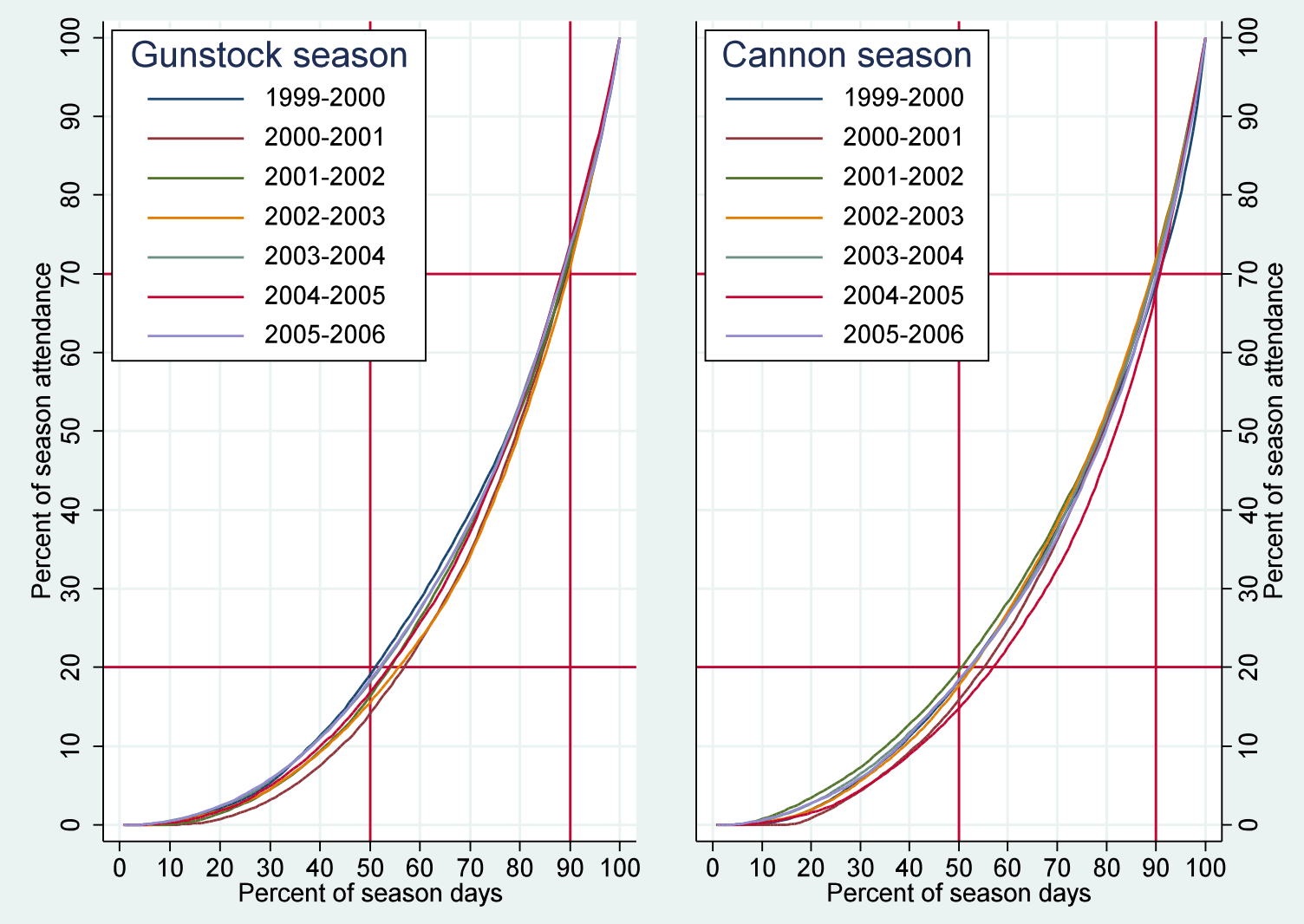

Figure 2: Percent of season attendance vs. percent of season days (ordered from lowest to highestattendance, or busiest) across seven seasons at two ski areas. For all seasons and both areas, about $30 \%$ of the total attendance occurred on the busiest $10 \%$ of the days.

To characterize the patterns behind good and bad days, we begin with "full" models predicting daily attendance across seven or nine seasons (roughly 870 or 1,030 days), based on:

(1) daily snowdepth, snowfall and temperature recorded at a "mountain" weather station not far from the ski area;

(2) daily snowdepth, snowfall and temperature recorded in the city of Boston, the nearest major metropolitan area (about 161 kilometers from Gunstock, and 225 from Cannon); 
(3) dummy variables denoting days of the week, omitting one day when average attendance was lowest; and

(4) for Gunstock only, a dummy variable marking days when the area was open for nighttime skiing.

Observing distinct seasonal cycles, we initially included month indicators as well. Monthly effects proved nonsignificant, however, after controlling for weather and snow conditions. Unlike weekend cycles, the seasonal cycles appear mainly climate-driven.

The time structure of weather effects on skier activity was not known in advance. For example, how is skier activity today affected by snow falling today? Or by snow falling yesterday, or the day before that? In the full models we covered these possibilities by including weather conditions from the same day (lag 0), previous day (lag 1), and two days previous (lag 2), for all six "mountain" and "city" weather indicators. Through experiments, we determined that disturbances in the full models were best specified as regular and multiplicative "seasonal" (weekly, not yearly) first-order autoregressive and moving average processes:

$\operatorname{ARIMA}(1,0,1) \times(1,0,1)_{7}$. Residuals from both full models, tested up to lag 24 , do not differ significantly from white noise. Squared correlations between observed and predicted values equal .67 for Gunstock and .55 for Cannon. Individual full-model regression coefficients on the weather variables appear unstable (high standard errors) and difficult to interpret, due to multicollinearity among closely-related lagged values such as yesterday's and today's snowdepth. Table I lists these coefficient estimates, $z$ tests of their significance, and other modeling results. 
Table I: Time series ARMAX models of daily attendance predicted by mountain (M) and city (C) weather conditions, and weekly cycles. "Lag 0 " refers to conditions that day, "lag 1" to the previous day, and so forth. Heteroskedasticity-robust standard errors and $z$ tests employed. Residuals (to at least lag 24) resemble white noise.

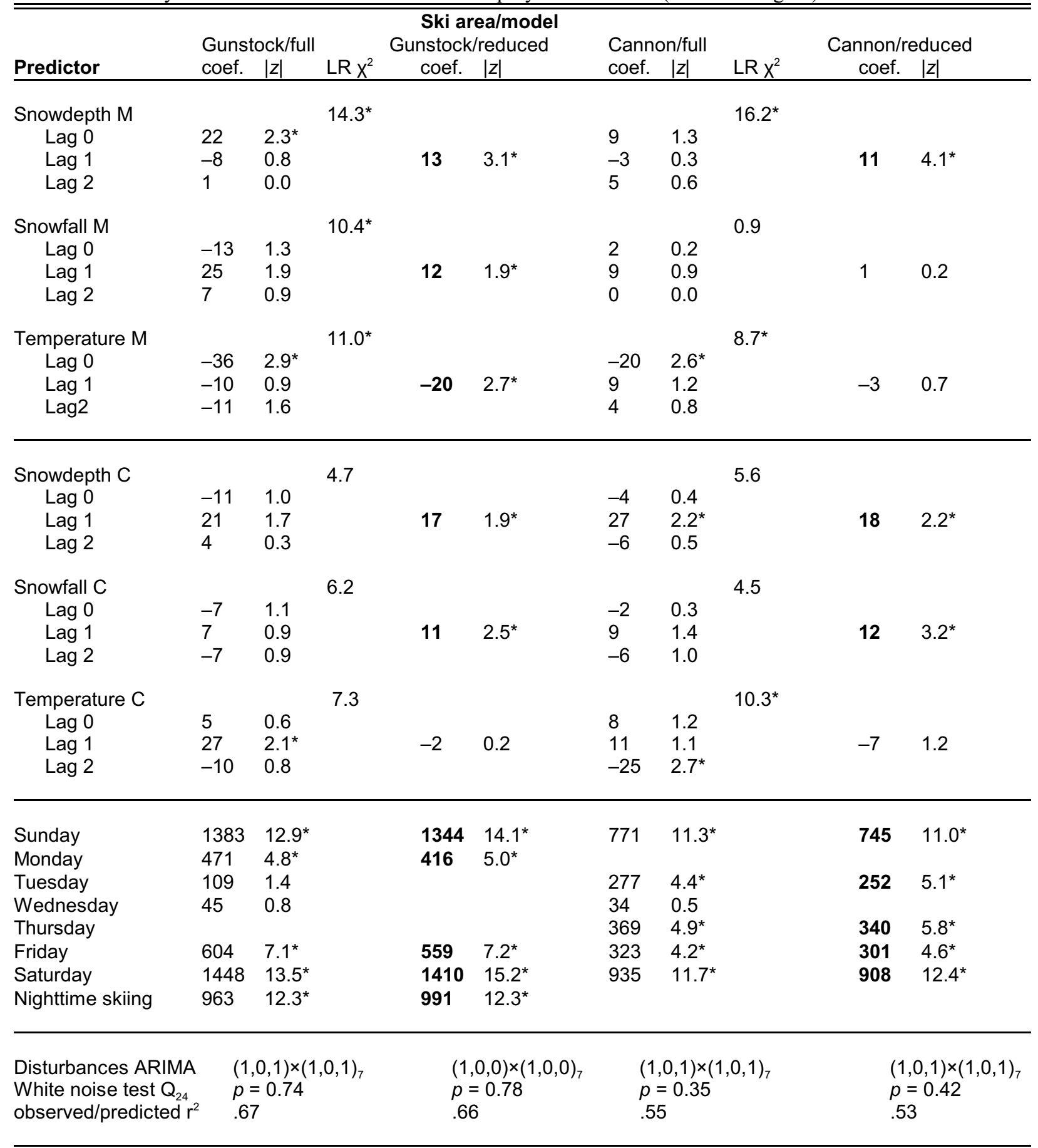

${ }^{\bar{*}} H_{0}:$ no effect rejected by LR $X_{3}^{2}$ test (sets of 3 coefficients) or 1 -tail $z$ test (single coefficient) at $\alpha=.05$. Significant reduced-model coefficients shown in bold. 
These models could be made more complex and arguably more realistic by including variables marking holiday periods, but as with the monthly terms we found little advantage to including holiday terms after weather and day-of-week had been entered. Indeed, multicollinearity and other symptoms suggest that the full models already are unnecessarily complex. Dropping lag 0 and lag 2 weather conditions, nonsignificant day-of-week dummies, and nonsignificant ARIMA disturbance terms led to the "reduced" models also shown in Table I. In these reduced models, predictions based only on yesterday's weather and snow conditions (in mountains and city), along with important days of the week, proved very nearly as good as those from the full models: $\mathrm{r}^{2}$ of .66 (compared with .67) for Gunstock, or .53 (compared with .55) for Cannon. The residuals still resemble white noise. While improving parsimony, we also gained more precise and interpretable coefficients, within an appealingly practical structure that predicts today's attendance from yesterday's weather. All effects have the hypothesized signs. Our discussion now focuses just on these reduced-model results.

Our models follow the basic ARMAX form

$$
y_{\mathrm{t}}=\mathbf{x}_{\mathrm{t}} \boldsymbol{\beta}+z_{\mathrm{t}}
$$

where $y_{\mathrm{t}}$ represents daily ski-area attendance at time t. $\mathbf{x}_{\mathrm{t}}$ is a matrix of exogenous predictor variables, and $\boldsymbol{\beta}$ the vector of coefficients on these $x$ variables. The $z_{\mathrm{t}}$ are "everything else" disturbances. For the full models of Table I we found it best to describe these disturbances as first-order autoregressive and moving average processes at both daily and multiplicative "seasonal" (weekly) lags — in time series notation, $\operatorname{ARIMA}(1,0,1) \times(1,0,1)_{7}$ :

$$
\left(1-\rho_{1} \mathrm{~L}\right)\left(1-\rho_{7,1} \mathrm{~L}^{7}\right) \mathrm{z}_{\mathrm{t}}=\left(1+\theta_{1} \mathrm{~L}\right)\left(1+\theta_{7,1} \mathrm{~L}^{7}\right) \varepsilon_{\mathrm{t}}
$$

or, rearranging [2a] and writing with subscripts instead of $\mathrm{L}$ (lag) operators:

$$
z_{t}=\rho_{1} z_{t-1}+\rho_{7,1} z_{t-7}-\rho_{1} \rho_{7,1} z_{t-8}+\varepsilon_{t}+\theta_{1} \varepsilon_{t-1}+\theta_{7,1} \varepsilon_{t-7}+\theta_{1} \theta_{7,1} \varepsilon_{t-8}
$$

In [2a] and [2b], the $\varepsilon$ terms represent random "white noise" (uncorrelated) errors. Expanding the disturbance term in [1] using [2b], our full models therefore have the form

$$
\begin{aligned}
y_{\mathrm{t}} & =\mathbf{x}_{\mathrm{t}} \boldsymbol{\beta}+\rho_{1}\left(y_{\mathrm{t}-1}-\mathbf{x}_{\mathrm{t}-1} \boldsymbol{\beta}\right)+\rho_{7,1}\left(y_{\mathrm{t}-7}-\mathbf{x}_{\mathrm{t}-7} \boldsymbol{\beta}\right)-\rho_{1} \rho_{7,1}\left(y_{\mathrm{t}-8}-\mathbf{x}_{\mathrm{t}-8} \boldsymbol{\beta}\right) \\
& +\theta_{1} \varepsilon_{\mathrm{t}-1}+\theta_{7,1} \varepsilon_{\mathrm{t}-7}+\theta_{1} \theta_{7,1} \varepsilon_{\mathrm{t}-8}+\varepsilon_{\mathrm{t}}
\end{aligned}
$$

The reduced models in Table I involve a simplified set of predictors ( $x$ variables), and in the case of Gunstock, drop the unneeded MA disturbance terms. Systematic components $\mathbf{x}_{t} \boldsymbol{\beta}$ in the reduced models are linear functions of dummy variables indicating significantly "big" days of the week, together with the previous day's snowdepth and snowfall (centimeters) as well as mean temperature $\left({ }^{\circ} \mathrm{C}\right)$ recorded at a nearby mountain location (Lakeport or Bethlehem) and at a more distant city location (Boston). For example, the reduced model for Cannon is

$$
\begin{aligned}
& y_{\mathrm{t}}=745 \text { sunday }+252 \text { tuesday }+340 \text { thursday }+301 \text { friday }+908 \text { saturday } \\
& +11 \text { beth_snowdepth } \mathrm{t}_{\mathrm{t}-1}+1 \text { beth_snowfall }_{\mathrm{t}-1}-3 \text { beth_temperature }_{\mathrm{t}-1} \\
& +18 \text { bos_snowdepth } h_{\mathrm{t}-1}+12 \text { bos_snowfall }_{\mathrm{t}-1}-7 \text { bos_temperature }_{\mathrm{t}-1} \\
& +.68\left(y_{\mathrm{t}-1}-\mathbf{x}_{\mathrm{t}-1} \boldsymbol{\beta}\right)+.57\left(y_{\mathrm{t}-7}-\mathbf{x}_{\mathrm{t}-7} \boldsymbol{\beta}\right)-(.68)(.57)\left(y_{\mathrm{t}-8}-\mathbf{x}_{\mathrm{t}-8} \boldsymbol{\beta}\right) \\
& -.20 \varepsilon_{\mathrm{t}-1}-.43 \varepsilon_{\mathrm{t}-7}+(.20)(.43) \varepsilon_{\mathrm{t}-8}+\varepsilon_{\mathrm{t}}
\end{aligned}
$$

where $\varepsilon_{\mathrm{t}}$ etc. are white-noise errors.

The unstandardized coefficients in Table I or equation [4] estimate changes in daily attendance - the number of skiers or snowboarders - expected from each one-unit increase in a 
predictor variable, if other predictors stay the same. For example, a one-centimeter increase in the previous day's snowdepth at Bethlehem, near Cannon, increases the predicted attendance by 11 skiers/snowboarders, other things being equal. $\{1\}$ A one-centimeter increase in the previous day's snowdepth in the more distant city of Boston increases predicted attendance somewhat more, by 18 skiers, even though Boston snow might have no bearing on Cannon-area conditions. Although our snow and weather proxies are rough indicators for actual ski-slope and urban-area conditions (and do not take snowmaking into account), these results support the "backyard hypothesis" that snow in urban backyards can be as important to ski businesses as snow in the mountains. Further encouragement for the backyard hypothesis appears in the Gunstock reduced model, with significant effects of 13 skiers/snowboarders for each centimeter of snowdepth yesterday in the mountains, and 17 for each centimeter in the city.

Cannon mountain is larger, at higher elevation, more northerly, and less sustained by local (including nighttime) visitors. At its lower and more southerly location, Gunstock has a shorter season and greater exposure to winter thaws and rains. We are not surprised to see a number of differences between the two areas' results in Table I, including differences in weekly cycles (which partly reflect business strategies). The similarities are nevertheless striking. Common findings include:

(1) the effectiveness of the basic ARMAX modeling approach based on yesterday's city and mountain weather, day of the week, and ARIMA disturbances;

(2) significant positive effects from yesterday's snowdepth in the mountains;

(3) significant positive effects from yesterday's snowdepth in the city, net of snowdepth in the mountains - confirming the backyard hypothesis;

(4) further supporting the backyard hypothesis, significant positive effects from yesterday's snowfall in the city, net of mountain conditions;

(5) no monthly effects, net of snow conditions and temperature; and

(6) large Saturday and Sunday effects (more than $40 \%$ of total skier-days) that should surprise no one, but serve to underline the importance of a handful of days to each season.

A crucial subset of weekends and holiday periods account for much of the annual attendance. Figure 3 visualizes this point with respect to the central part of one very good ski season at Cannon, 2002-2003. Jagged lines track the day-to-day variations in actual and predicted attendance from December 1 to April 10 (30 to 160 days after our arbitrary zero point, November 1). Predictions were calculated from the reduced model of Table I (equation [4]), although that model applies to all days for all seven ski seasons 1999-2006, not just the central 2002-2003 period shown. In the background of Figure 3, a light-gray mountain depicts the rise and fall of daily snowdepth reported from the mountain town of Bethlehem. A lower, darker mountain depicts the more transient snowdepth in Boston. The two highest peaks in attendance, around days 60 and 110, roughly correspond to the two snowiest periods in Boston. 


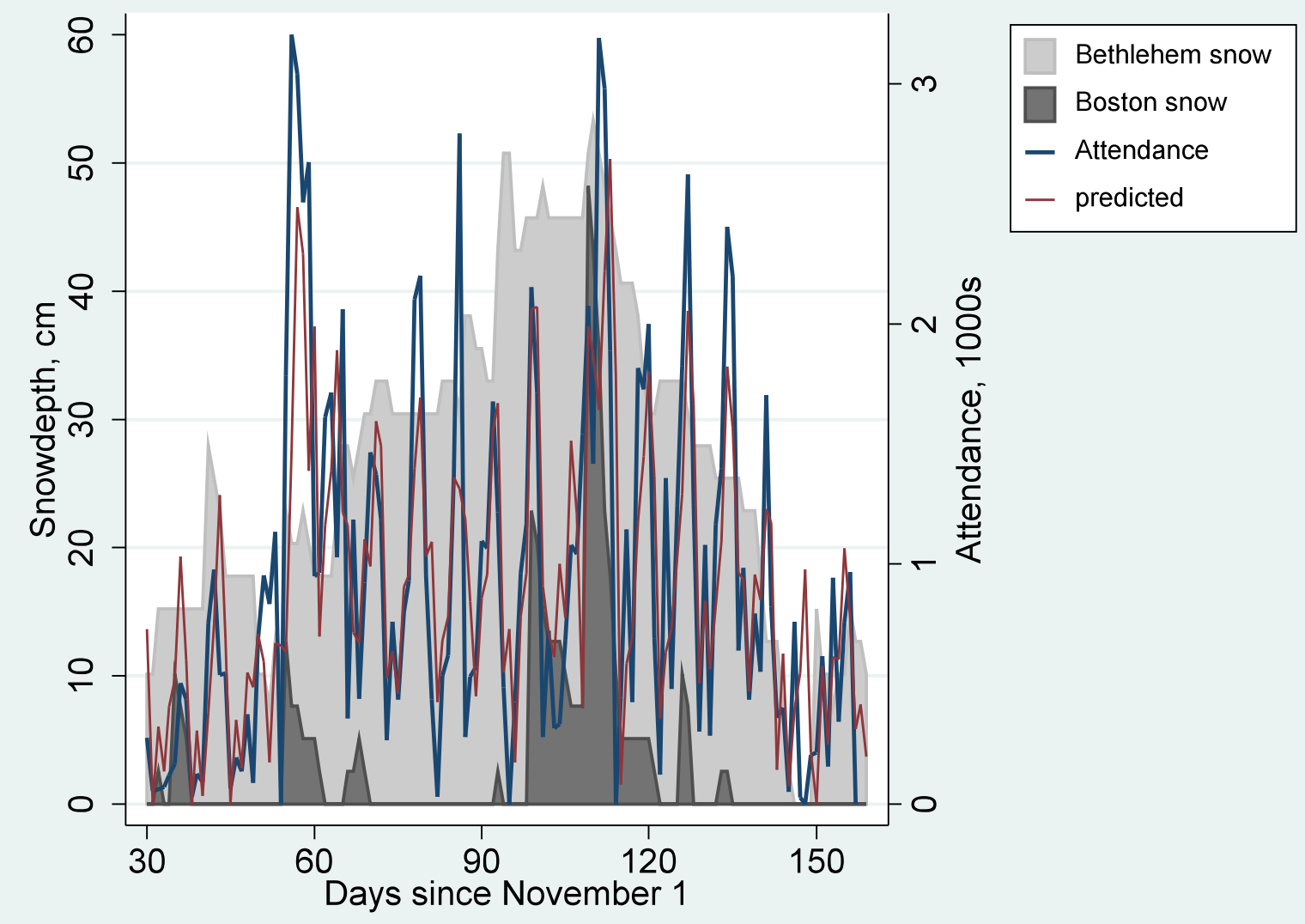

Figure 3: Actual and reduced-model predictions of attendance at Cannon during the 2002-03 ski season, graphed with snowdepth in Boston and in the White Mountains town of Bethlehem.

Figure 4 contains nine small graphs of similar design, depicting data and reduced-model predictions for all the analyzed ski seasons at Gunstock. In Figure 4, the light-gray background mountains indicate snowdepth reported from the nearby town of Lakeport, and dark gray again indicates Boston. 


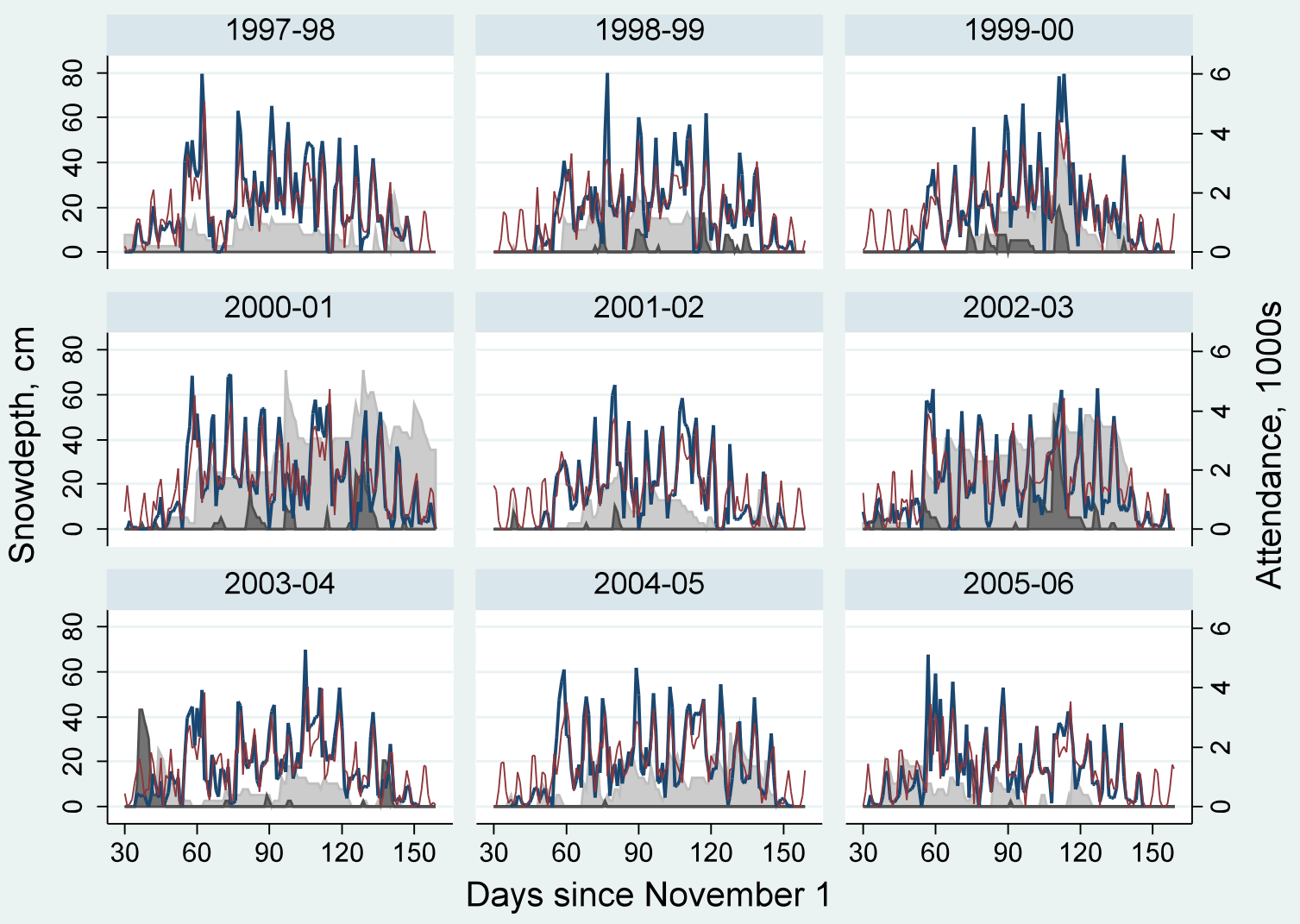

Figure 4: Actual and reduced-model predictions of attendance at Gunstock through nine ski seasons, graphed with snowdepth in Boston and in the mountain town of Lakeport.

The gray background mountains in Figure 4 paint a snow portrait of nine winters, visualizing their year-to-year variation. Some winters, notably $2000-01$ and 2002-03, featured relatively deep and continuous snow cover in the mountains, with intermittent periods of substantial snow cover in Boston. Others such as 2003-04 and 2005-06 saw only shallow and discontinuous snow cover in the mountains, and very little in Boston. Skier activity likewise varies from year to year. Spikes in attendance mark weekends and holidays. The highest spikes occur at different times from one year to the next, however, because they are influenced by snow conditions and weather. Some years had many good weekends, whereas others appear dominated by a few. The winter of 2005-06, among the least snowy on record, exhibits comparatively few and mild attendance peaks.

\section{IN THE CONTEXT OF CLIMATE CHANGE}

Recent analyses of the ski business and climate change have emphasized the adaptive importance of snowmaking (e.g., Scott 2006; Scott et al. 2006a, 2006b). So long as temperatures stay low enough to make and keep snow, and the necessary water and infrastructure exist, ski areas can 
manufacture snow that is deeper and more durable than what snowfall provides. Snowmaking costs millions, but has become a competitive and climatic necessity in many places. Smaller, less capitalized resorts, and those in marginal climates, have trouble making the necessary investments - a factor in their high failure rate, and the industry's consolidation into a smaller number of larger resorts (Hamilton et al. 2003a; NELSAP 2006). One ski-business report discussed New Hampshire's low-snow winter of 2005-06 (see Figure 4) as follows:

"A key contributor to the business levels during a winter with little natural snow can be directly attributed to the state's vast snowmaking efforts. New Hampshire Governor John Lynch felt this past winter's effort was so vital to the state's economy that he issued an official commendation to New Hampshire's snowmakers." (SkiNH 2006b)

This is not to say that business levels remained normal, despite little snow. As Figure 5 shows, the 2005-06 attendance was low, like the snow cover. Without major snowmaking, however, attendance would have been even lower. Figure 5 demonstrates that although snowmaking surely cushions the impact of low-snow seasons, it has not made the business independent of natural snow. The gap between highest and lowest-snow years is on the order of 100,000 skierdays at these two areas alone. $\{2\}$
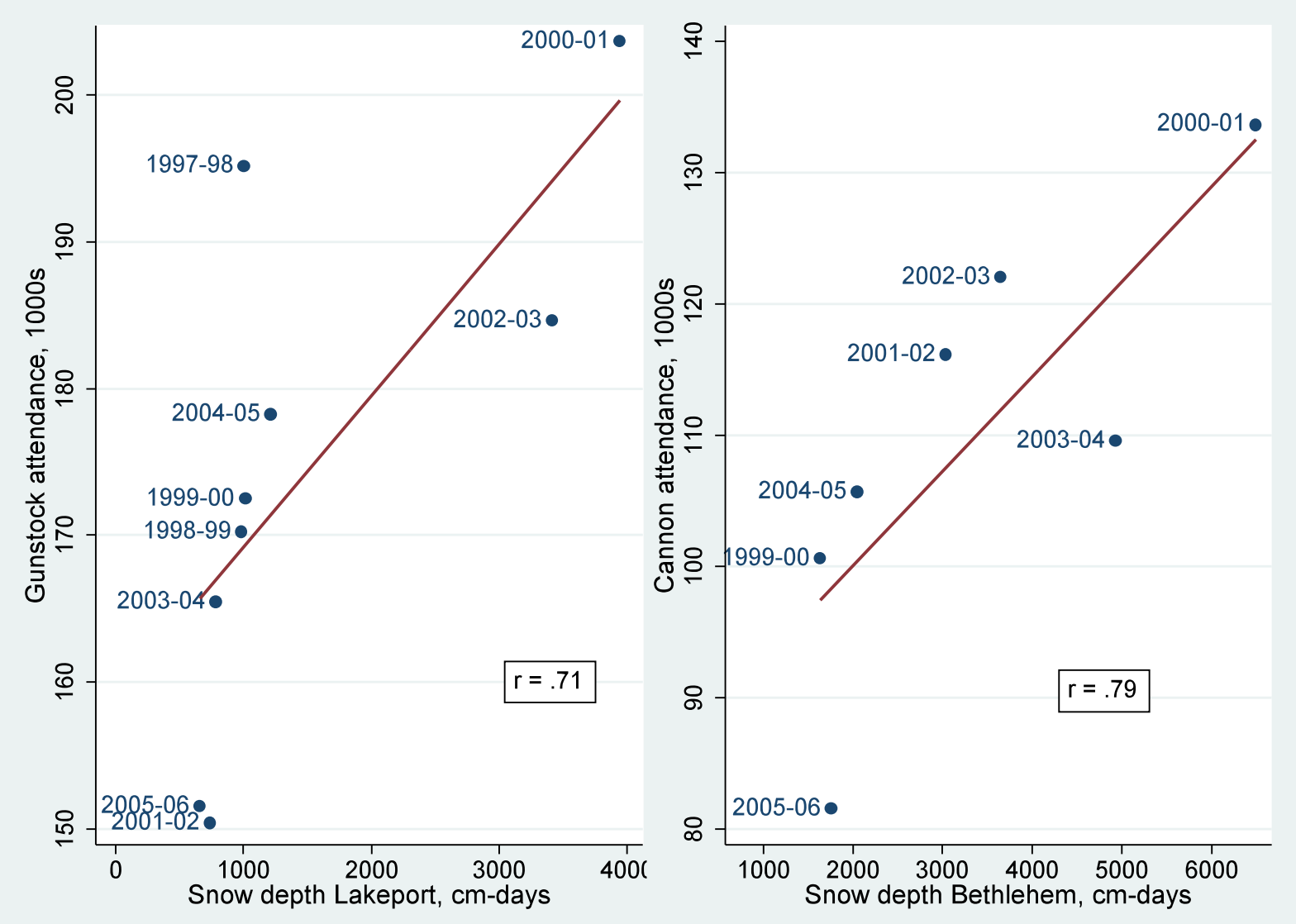

Figure 5: Annual attendance at two ski areas vs. cumulative annual centimeter-days of snow cover at nearby towns. Attendance and snowdepth totals aggregated from daily data. 
One limitation on snowmaking as a substitute for snowfall is the fact that snowmaking, too, depends on winterlike weather. During the seasons graphed in Figure 5, the number of December through March days with average temperatures above freezing ranged from 6 at Bethlehem and 19 at Lakeport, in the cold winter of 2000-01, up to 38 at Bethlehem and 55 at Lakeport, in the warm winter of 1999-00. Note that the cold winter of 2000-01 was also the most snowy and highest-attendance in Figure 5. Conversely, the warm winter of 1999-00 was among the least snowy and lowest-attendance. Within each season, moreover, days with less snow often also are warmer, which can complicate snowmaking when it is needed the most.

Skiers individually might adapt to weather by waiting until poor conditions improve, or by skiing more frequently once conditions become good. But such behavioral flexibility evidently is not enough to overcome the impact of low-snow winters, as seen in Figure 5. We saw no large-scale pattern of skiers adapting to a poor start of the season by increasing their attendance later on. At both Cannon and Gunstock, total early-season (November through January) attendance exhibited a weak positive correlation with late-season (February through April) attendance, instead of the negative correlation one might expect if many skiers were compensating within seasons. Daily autocorrelations appear predominantly positive or zero, as well.

Figure 5, like the modeling results in Table I, confirms that skier activity still depends upon weather. Snowdepth in the mountains matters, controlling for temperature (noteworthy because low temperatures permit artificial snowmaking). Moreover, both snowdepth and snowfall in the city matter, although they do not necessarily reflect snow conditions in the mountains. If this backyard effect reflects ignorance, then education is the cure - skiers could be persuaded that great skiing exists in the mountains, even when their backyard is bare. The backyard effect might also partly reflect subtler dynamics, such as people who feel less like skiing, or perceive more activity choices, when conditions are not wintry near home.

Weather follows climate, and the weather/snow indicators analyzed above have been moving with more general climate trends. Mean annual temperatures over the Northeastern US increased by an average of $0.08^{\circ} \mathrm{C} /$ decade over the past century, a trend that steepens to $0.25^{\circ} \mathrm{C} / \mathrm{decade}$ in the past three decades, and becomes even more pronounced, $0.70^{\circ} \mathrm{C} / \mathrm{dec}$ ade, if we focus specifically on winters. The Northeast's observed winter warming has been accompanied by decreases in snowfall amounts, snowpack depth, and ratio of snow to total precipitation (Hayoe et al. 2006). Both the observed trends and the consensus of nine atmosphere-ocean general circulation models (AOGCMs) support a conclusion that "the impacts of climate change are already being experienced across the NE" (Hayoe et al. 2006).

Earlier studies noted similar warming trends in New England (NERA 2001) and New Hampshire (Hamilton et al. 2003a) specifically. Over the period of historical records from 1896 through 2006, the mean December through March winter temperature in New Hampshire warmed by $3.7^{\circ}$ $\mathrm{F}\left(2.1^{\circ} \mathrm{C}\right)$, a significant linear rise. As seen in Figure 6 the main warming occurred not linearly but in two steps, roughly 1910-1945 and (more steeply) after 1975-parallel to regional trends (Hayoe et al. 2006, in review; also see NECIA 2006) and also to the more general rise in global 
mean temperatures (e.g., Zweirs and Weaver 2000). Although the timing of New Hampshire winter warming parallels the global, all-season trend, it has been more pronounced. As mean winter temperature rose closer to the melting point in the late 20th century, and warm winter days became more frequent, many New Hampshire ski areas went out of business (Hamilton et al. 2003a).

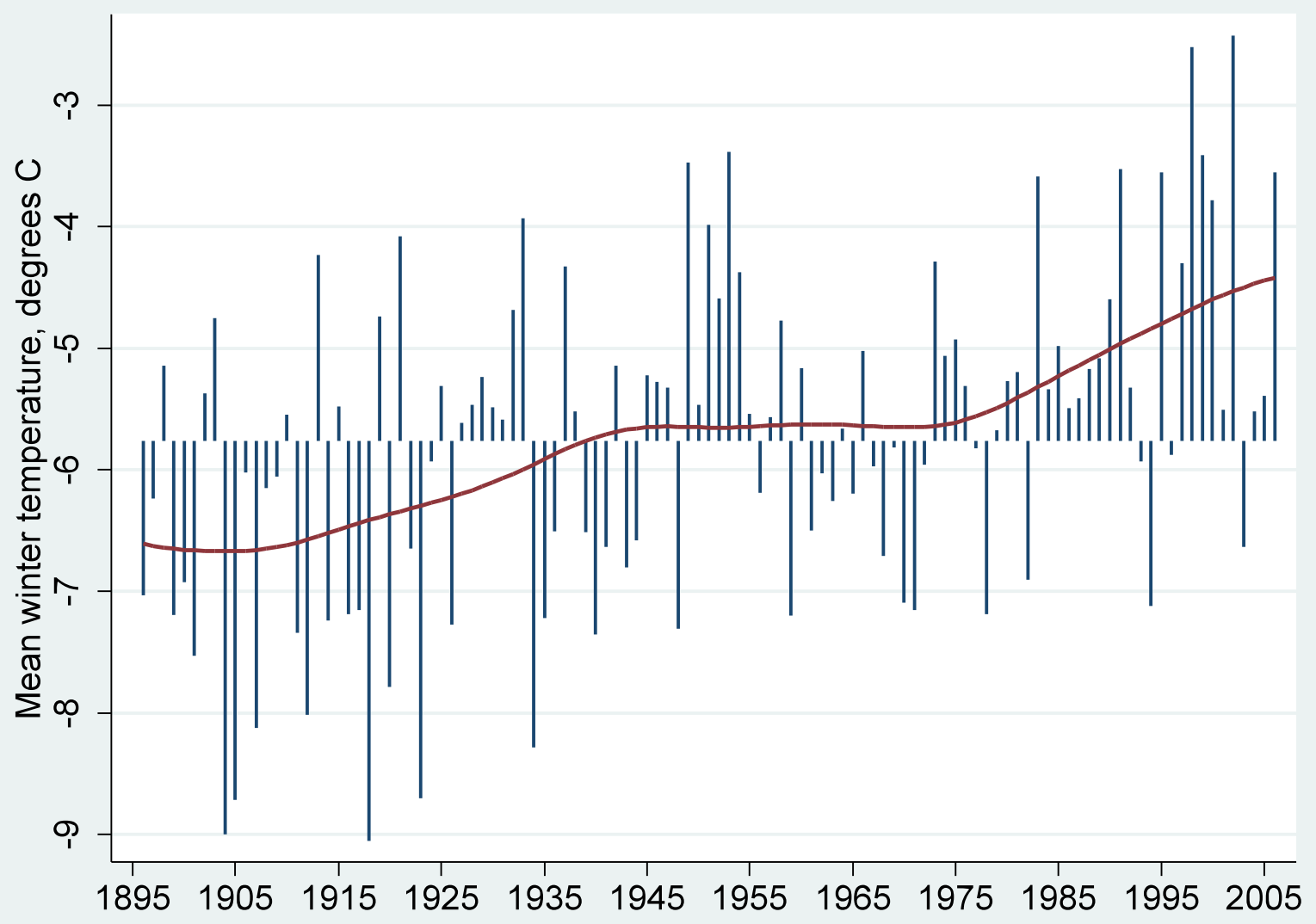

Figure 6: Mean December-March temperature in New Hampshire, 1896-2006. Shown as deviations from the overall mean, with lowess regression curve. Linear trend $+2.1^{\circ} \mathrm{C}\left(+3.7^{\circ} \mathrm{F}\right)$. The mean winter temperature was constructed from an updated 2007 issue of the United States Historical Climate Network (USHCN) (Karl et al. 1990). These USHCN stations for New Hampshire were then used to derive climate divisional data according to the methods of Keim et al. (2003, 2005).

Looking forward, the New England Regional Assessment report (NERA 2001) described results from two AOGCMs that project rises of 3 to $7^{\circ} \mathrm{C}$ in minimum winter temperature over $21 \mathrm{st}$ century, assuming that greenhouse gas concentrations rise by $1 \%$ of current levels per year. Regional models also project decreasing winter snow depth in the 21 st century, including the particular locations of our two case-study ski areas (Scott, personal communication). Hayoe et al. (2006, in review) note that, although an ensemble of eight current AOGCMS generally do well in modeling historical Northeastern US temperature trends, none succeed in reproducing the rapid $0.7^{\circ} \mathrm{C} /$ decade increase in winter temperatures observed over 1970-2000. This difficulty might reflect their limitations in modeling regional snow cover. The (possibly conservative) 
ensemble projected further winter warming on the order of +1.1 to $+3.1^{\circ} \mathrm{C}$ under different emissions scenarios by 2064, and more by century's end. Warming trends would shift the distribution of daily temperatures upwards, thereby "decreasing the number of days that fall below cold-temperature thresholds" (Hayoe et al. 2006). Such projections, together with our demand-side findings about weather effects, suggest steeper challenges ahead for this industry.

\section{DISCUSSION}

Nearly three decades ago, as global warming began its not-yet-recognized takeoff, Dunlap and Catton (1979:243) described the emergence of environmental sociology, which asserted that "physical environments can influence (and in turn be influenced by) human societies and behavior." The development signaled, in principle, a rejection of the idea that researchers can explain social facts only in terms of other social facts. Perhaps most of us now agree, but in practice the goal of integrating environmental indicators as variables in social research has not been simple. Much environmental sociology remains focused within the social domain, making progress in research on environment-related policies, movements, attitudes or behavior. Environmental conditions themselves then appear indirectly, as background concerns or objects of social construction, instead of direct measures that covary as cause or effect with human activities. More formal integration has been limited by the fact that environmental and social data tend to be observed across different units, at different scales, and have different dynamics.

The two obvious dimensions for integrating environmental variables are time and space. Spatial integration occurred classically in cross-sectional research where, for example, nations, states, counties or cities comprise the units of analysis. Environmental variables available for such units include measures of resource consumption (e.g., oil, electricity, or proxies based on wealth), effluent emissions (e.g., $\mathrm{CO}_{2}$, solid wastes, hazardous wastes), environmental quality (e.g., air, water or soil contamination), or mean climate (for examples see Adeola 2001; Brooks and Sethi 1997; Carson, Jeon and McCubbin 1997; Dietz and Rosa 1997; Ehrhardt-Martinez 1998; Hope et al. 2006; Jorgenson 2004; Rasker 2006; Rudel 1999; York, Rosa and Dietz 2003).

Environmental circumstances such as climate-change vulnerability can be considered among the background factors affecting individual survey respondents whose locations are known (e.g., Zahran et al. 2006). Recent advances in modeling and remote sensing have made technicallydefined spatial units such as grid cells or satellite-image pixels available for integrated research (e.g., Grove et al. 2006). Spatially-integrated data of most types can be mapped or, where enough observations exist, analyzed through multiple regression and related methods.

Alternatively, we might employ time as the integrating dimension, using years, months or days for our units of analysis. Yearly time series of aggregated social data are widely available, as are yearly series of business and economic statistics, resource-use measures such as fishery landings, farm harvests, mine output or timber cutting, some ecological monitoring, and weather/climate summaries at many scales. Yearly time series permit simple integration and, importantly, focus our attention on change. Such data tend to be limited, however, in the length of available 
series - often, just a few decades or less, not enough to support modeling. Consequently, their analysis has often been informal, using time plots and narratives to infer connections between environmental and societal change (e.g., Hamilton et al. 2000, 2003a, 2003b, 2004a, 2004b).

Daily data of interest to environmental sociology are less common. Where they do exist, however, the rich information contained in hundreds of daily observations could open new analytical doors. This paper began as a "test of concept," investigating whether ARMAX modeling of daily time series could yield practical new information regarding the specialized topic of climate impacts on ski areas. Time series modeling provides a toolkit that might prove broadly useful for this and other types of detailed impact studies.

Our first results are encouraging, although it is too soon to generalize from the findings. Whether our two case studies will turn out to be representative of other ski areas, and how things differ elsewhere, are questions best addressed through replications using more diverse samples. As steps in that direction, we are currently exploring other Northeastern case studies, as well as parallel work in Colorado where trends in mountain snowpack have been a concern (Mote et al. 2005). A more ambitious step will be to develop ways to look forward from daily-attendance models, driving them with future winter days generated stochastically from place-adjusted models under alternative climate scenarios. Such integration should yield new insights about the role of variability in this very quick-response domain.

\section{NOTES}

\{1\} Effects in the reported models are linear. Nonlinear specifications, such as a decreasing impact from additional snow as the base becomes deeper, seem quite plausible. We watched for this possibility by trying log snowdepth instead of snowdepth as a predictor, but saw no consistent improvement in fit. Log versions of the dependent and other variables likewise did not yield better models, so we retained the simple linear versions.

\{2\} Although the same set of years comprises the data points in both panels of Figure 5, some years (notably 2001-02) plot at different relative $x$-axis positions, reflecting divergent snow experiences at two mountain locations less than 50 miles $(80 \mathrm{~km})$ apart. This observation highlights snow variability and the importance of location-specific analyses. 


\section{REFERENCES}

ACACIA. 2000. Tourism and recreation. In Assessment of Potential Effects and Adaptations for Climate Change in Europe, ed. M. Parry, 217-226. Norwich, UK: University of East Anglia, Jackson Environmental Institute.

Adeola, F. 2001. Environmental injustice and human rights abuse: The States, MNCs, and Repression of Minority Groups in the World System. Human Ecology Review 8:39-59.

Badke, C. 1991. Climate Change and Tourism: The Effect of Global Warming on Killington, Vermont. Unpublished undergraduate thesis, Deparment of Geography. Waterloo, Canada: University of Waterloo.

Beniston, M., F. Keller, B. Kofi, and S. Goyette. 2003a. Snow pack in the Swiss Alps under changing climatic conditions: An empirical approach for climate impact studies. Theoretical and Applied Climatology 74:19-31.

Beniston, M., F. Keller, B. Kofi, and S. Goyette. 2003b. Estimates of snow accumulation and volume in the Swiss Alps under changing climatic conditions. Theoretical and Applied Climatology 76:125-140.

Breiling, M., and U.P. Charamaza. 1999. The impact of global warming on winter tourism and skiing: A regionalised model for Austrian snow conditions. Regional Environmental Change $1: 4-14$.

Brooks, N., and R. Sethi. 1997. The distribution of pollution: Community characteristics and exposure to air toxics. Journal of Environmental Economics and Management 32:233-250.

Cannon Mountain. 2006. http://www.cannonmt.com, accessed 4 August 2006.

Carson, R., Y. Jeon, and D. McCubbin. 1997. The relationship between air pollution emissions and income: U.S. data. Environment and Development Economics 2: 433-450.

Dietz, T. and E. Rosa. 1997. Environmental impacts of population and consumption. In Environmentally Significant Consumption: Research Directions, P. Stern, T. Dietz, V. Ruttan, R. Socolow, and J. Sweeney eds., 92-99. Washington, D.C.: National Academy Press.

Doesken, N.J., and A. Judson. 1997. The Snow Booklet: A Guide to the Science, Climatology, and Measurement of Snow in the United States. Colorado Climate Center, Department of Atmospheric Science, Colorado State University.

Dunlap, R.E. and W.R. Catton, Jr. 1979. Environmental Sociology. Annual Review of Sociology 5:243-273. 
Ehrhardt-Martinez, K. 1998. Social determinants of deforestation in developing countries: A cross-national study. Social Forces 77:567-586.

Elsasser, H. and R. Bürki. 2002. Climate change as a threat to tourism in the Alps. Climate Research 20:253-257.

Elsasser, H. and P. Messerli. 2001. The vulnerability of the snow industry in the Swiss Alps. Mountain Research and Development 21(4):335-339.

Fukushima T., M. Kureha, N. Ozaki, Y. Fujimori, and H. Harasawa. 2002. Influences of air temperature change on leisure industries: Case study on ski activities. Mitigation and Adaptation Strategies for Global Change 7(2):173-189.

Galloway, R. 1988. The potential impact of climate changes on Australian ski fields. In Greenhouse: Planning for Climatic Change, ed. G. Pearlman, 428-437. Melbourne, AU: CSIRO.

Gössling, S., and C. Hall, eds. 2005. Tourism and Global Environmental Change; Ecological, Social, Economic and Political Inter-relationships. London: Routledge.

Grove, J.M., M.L. Cadenasso, W.R. Burch, Jr., S.T.A. Pickett, K. Schwartz, J. O’Neil-Dunne, M. Wilson, A. Troy and C. Boone. 2006. Data and Methods Comparing Social Structure and Vegetation Structure of Urban Neighborhoods in Baltimore, Maryland. Society and Natural Resources 19:117-136.

Grove, JM; Cadenasso, ML; Burch, Jr., WR; Pickett, STA.; Schwartz, K; O’Neil-Dunne, J; Wilson, M; Troy, A; Boone, C. 2006. Data and Methods Comparing Social Structure and Vegetation Structure of Urban Neighborhoods in Baltimore, Maryland. Society and Natural Resources 19:117-136.

Gunstock Mountain Resort. 2006. http://www.gunstock.com/about_us/, accessed 4 August 2006.

Hamilton, J. D. 1994. Time Series Analysis. Princeton: Princeton University Press.

Hamilton, L. C. 2006. Statistics with Stata 9. Belmont, CA: Duxbury.

Hamilton, L.C., P. Lyster and O. Otterstad. 2000. Social change, ecology and climate in $20^{\text {th }}$ century Greenland. Climatic Change 47(1/2):193-211.

Hamilton, L.C., D.E. Rohall, B.C. Brown, G. Hayward, and B.D. Keim. 2003a. Warming winters and New Hampshire's lost ski areas: An integrated case study. International Journal of Sociology and Social Policy 23(10):52-73. 
Hamilton, L.C., B.C. Brown and R.O. Rasmussen. 2003b. West Greenland's cod-to-shrimp transition: Local dimensions of climatic change. Arctic 56(3):271-282.

Hamilton, L.C., R.L. Haedrich and C.M. Duncan. 2004a. Above and below the water: Social/ecological transformation in northwest Newfoundland. Population and Environment 25(3):195-215.

Hamilton, L.C., S. Jónsson, H. Ögmundardóttir, and I. Belkin. 2004b. Sea changes ashore: The ocean and Iceland's Herring Capital. Arctic 57(4):325-335.

Harvey, A. C. 1989. Forecasting, Structural Time Series Models and the Kalman Filter. Camb ridge: Cambridge University Press.

Hantel, M. 2000. Climate sensitivity and snow cover duration in Austria. International Journal of Climatology. 20:615-640.

Hayhoe, K., C.P. Wake, J. Bradbury, T. Huntington, L. Luo, M.D. Swartz, J. Sheffields, B. Anderson, A. DeGaetano, D. Wolfe and E. Wood. 2006. Past and future changes in climate and hydrological indicators in the U.S. Northeast. Climate Dynamics 28(4):381-407.

Hayoe, K., C. Wake, B. Anderson, J. Bradbury, A. DeGaetano, A. Hertel, X-Z Liang, E. Maurer, D. Wuebbles and J. Zhu. In review. Quantifying the regional impacts of global climate change: Evaluating AOGCM simulations of past and future trends in the temperature, precipitation, and atmospheric circulation in the Northeast US.

Hope, D., C. Gries, D. Casagrande, C.L. Redman, N. Grimm and C. Martin. 2006. Diversity of spatial variation in plant diversity across the Central Arizona-Phoenix ecosystem. Society and Natural Resources 19:101-116.

Huber, P. J. 1967. The behavior of maximum likelihood estimates under non-standard conditions. In Proceedings of the Fifth Berkeley Symposium on Mathematical Statistics and Probability, 221-233. Berkeley: University of California Press.

Huntington, T.G., G.A. Hodgkins, B.D. Keim, and R.W. Dudley. 2004. Changes in the proportion of precipitation occurring as snow in New England (1949-2000). Journal of Climate 17(13):2626-2636.

IPCC (Intergovernmental Panel on Climate Change). 2001. Climate Change 2001: Impacts, Adaptation and Vulnerability. Third Assessment Report. Cambridge: Cambridge University Press.

Karl, T. R., C. N. Williams, Jr. and F. T. Quinlan. 1990. United States Historical Climatology Network (HCN) Serial Temperature and Precipitation Data. ORNL/CDIAC-30, NDP-019/R1. 
Carbon Dioxide Information Analysis Center, Oak Ridge National Laboratory, U.S. Department of Energy, Oak Ridge, Tennessee.

Keim, B. D., and B. Rock. 2001. The New England Region's Changing Climate. In Preparing for a Changing Climate: The Potential Consequences of Climate Variability and Change. The New England Regional Assessment Overview, 8-17. Durham, NH: University of New Hampshire.

Keim, B.D., A. Wilson, C.P. Wake, and T. Huntington. 2003. Are there spurious temperature Trends in the United States Climate Division Database? Geophysical Research Letters 30(7):10.1029/2002GL016295.

Keim, B.D., M.R. Fischer and A. Wilson. 2005. Are there spurious precipitation trends in the United States Climate Division Database? Geophysical Research Letters 32, L04702, doi:10.1029/2004GL021985.

Koenig, U., and B. Abegg. 1997. Impacts of climate change on winter tourism in the Swiss Alps. Journal of Sustainable Tourism 5(1):46-58.

Koenig, U. 1999. Climate change and snow tourism in Australia. Geographica Helvetica 54(3):147-157.

Jorgenson, A. 2004. Uneven processes and environmental degradation in the world-economy. Human Ecology Review 11:103-117.

Laternser, M. and M. Schneebeli. 2003. Long-term snow climate trends of the Swiss Alps (1931-99). International Journal of Climatology 23(7):733-750.

McBoyle, G., and G. Wall. 1992. Great Lakes skiing and climate change. In Mountain Resort Development, A. Gill and R. Hartman eds. Burnaby, BC: Simon Fraser University.

Mitchell, M. N. 2004. A Visual Guide to Stata Graphics. College Station, TX: Stata Press.

Mote, P. W., A. F. Hamlet, M. P. Clark, and D. P. Lettenmaier. 2005. Declining mountain snowpack in western North America. Bulletin of the American Meteorological Society 86(1):39-49.

NCDC. 2006. National Climate Data Center FTP site. ftp://ftp.ncdc.noaa.gov/pub/data/cirs/, accessed 30 May 2006.

NECIA. 2006. Climate Change in the U.S. Northeast: A Report of the Northeast Climate Impacts Assessment. Cambridge, MA: Union of Concerned Scientists. 
NELSAP. 2006. New England Lost Ski Areas Project. http://www.nelsap.org/, accessed 4 August 2006.

NERA (New England Regional Assessment Group). 2001. Preparing for a Changing Climate: The Potential Consequences of Climate Variability and Change. Durham, NH: University of New Hampshire.

New England Ski Guide. 2006. http://www.newenglandski.com, accessed 4 August 2006.

New England Ski Museum. 2006. http://www.skimuseum.org/, accessed 4 August 2006.

Nolin, A.W. and C. Daly. 2006. Mapping "at risk" snow in the Pacific Northwest. Journal of Hydrometeorology 7(5):1164-1171.

OECD (Organisation for Economic Co-operation and Development). 2007. Climate Change in the European Alps: Adapting Winter Tourism and Natural Hazards Management. http://www.oecd.org/document/45/0,2340,en_2649_34361_37819437_1_1_1_1,00.html accessed 6 Jauary 2007.

Palm, B. 2001. Skiing with Climate Change: An Analysis of Climate Change and the Consequences for the Ski Industry of New Hampshire and Vermont. Masters Thesis, Oxford University.

Rasker, R. 2006. An exploration into the economic impact of industrial development versus conservation on Western public land. Society and Natural Resources 19:191-207.

Royall, R. M. 1986. Model robust confidence intervals using maximum likelihood estimators. International Statistical Review 54:221-226.

Rudel, T. 1999. Critical regions, ecosystem management, and human ecosystem research. Society and Natural Resources 12:257-260.

Scherrer, S.C., C. Appenzeller C and M. Laternser. 2004. Trends in Swiss Alpine snow days: The role of local- and large-scale climate variability. Geophysical Research Letters 31(13) doi:10.1029/2004GL020255

Scott, D, D., Dawson, J, Jones, B. forthcoming. Climate change vulnerability of the Northeast US winter tourism sector. Mitigation and Adaptation Strategies to Global Change.

Scott, D., and G. McBoyle. 2006. Climate change adaptation in the ski industry. Mitigation and Adaptation Strategies for Global Change http://dx.doi.org/10.1007/s11027-006-9071-4 
Scott, D., G. McBoyle, and B. Mills. 2003. Climate change and the skiing industry in Southern Ontario. Climate Research 23(2):171-181.

Scott, D., G. McBoyle, G. Mills, and A. Minogue. 2006a. Climate change and the sustainability of ski-based tourism in eastern North America: A reassessment. Journal of Sustainable Tourism 14(4):376-398.

Scott, D., G. McBoyle, and A. Minogue. 2006b. Climate change and Quebec's ski industry. Global Environmental Change doi:10.1016/j.gloenvcha.2006.05.004

Ski NH. 2006a. http://winter.skinh.com, accessed 4 August 2006.

Ski NH. 2006b. http://www.skinh.com/businessresultsrelease.cfm, accessed 4 August 2006.

Stata Corporation. 2005a. Stata Time-Series Reference Manual, release 9. College Station, TX: Stata Press.

Stata Corporation. 2005b. User's Guide, release 9. College Station, TX: Stata Press.

Tufte, E.R. 1990. Envisioning Information. Cheshire CT: Graphics Press.

Tufte, E.R. 1997. Visual Explanations: Images and Quantities, Evidence and Narrative. Cheshire CT: Graphics Press.

Tufte, E.R. 2001. The Visual Display of Quantitative Information. Cheshire CT: Graphics Press.

White, H. 1980. A heteroskedasticity-consistent covariance matrix estimator and a direct test for heteroskedasticity. Econometrica 48:817-830.

White, H. 1982. Maximum likelihood estimation of misspecified models. Econometrica 50:1-25.

World Tourism Organization. 2003. Climate Change and Tourism: Proceedings of the First International Conference on Climate Change and Toursim. Djerba, Tunisia, 9-11 April. Madrid, Spain: World Tourism Organization.

York, R., E. Rosa, and T. Dietz. 2003. Footprints on the earth: The environmental consequences of modernity. American Sociological Review 68:279-300.

Zahran, S., S.D. Brody, H. Grover and A. Vedlitz. 2006. Climate change, vulnerability and policy support. Society and Natural Resources 19:771-789. 
Zwiers, F. W. and A. J. Weaver. 2000. The causes of 20th century warming. Science 290(15 December):2081-2083.

\section{ACKNOWLEDGMENTS}

We are grateful to Amy Bassett (Marketing Director, Cannon Mountain) and Greg Goddard (General Manager, Gunstock Mountain Resort), who generously provided the attendance data that made this work possible. James Hamilton gave helpful suggestions on an earlier draft; Cameron Wake and Daniel Scott shared their own work in progress. 